\title{
Price Effects of Landfills on Residential Housing in Lagos, Nigeria
}

\author{
O.A.Akinjare (Corresponding author) \\ Department of Estate Management, School of Environmental Sciences \\ College of Science and Technology, Covenant University, Ota, Ogun State, Nigeria \\ Tel: 234-803-806-5545Ｅ-mail: omoladeogah@yahoo.co.uk
}

S.A.Oloyede

Department of Estate Management, School of Environmental Sciences

College of Science and Technology, Covenant University, Ota, Ogun State, Nigeria

Tel: 234-803-472-2469_E-mail: samoloye49@yahoo.com

\section{C.A.Ayedun}

Department of Estate Management, School of Environmental Sciences

College of Science and Technology, Covenant University, Ota, Ogun State, Nigeria

Tel: 234-803-390-0681Ｅ-mail: caayedun@yahoo.com

O.C Oloke

Department of Estate Management, School of Environmental Sciences

College of Science and Technology, Covenant University, Ota, Ogun State, Nigeria

Tel: 234-703-224-4140 E-mail: c_yinkaoloke@yahoo.com

Received: February 9, 2011 Accepted: March 11, 2011 doi:10.5539/ijms.v3n2p64

\begin{abstract}
The question as to whether solid waste landfills affect residential property values has long been a subject of controversy and debate. Previous studies have resulted in mixed conclusions. This study examines four landfill sites in Lagos which differ in size, operating status and history. The relationship between each landfill and property values were measured based on distances of $1.2 \mathrm{~km}$ radii away from the landfill locations and the measurements were based on the interval of 300meters up to 1200 meters in concentric rings.

The result of the study indicated that across the four landfill sites, increase in property values were evident as distance away from the landfills increased indicating that residential houses in close proximity to the landfills suffered value loss. Property appreciation relative to distance averaged $5.75 \%$ within the concentric rings for all four landfills.
\end{abstract}

Keywords: Landfill, Distance, Property value, Residential property

\section{Introduction}

The fact has been established that the establishment and operation of a landfill in any location creates negative externalities which include environmental stigma and damage resulting to negative impacts such as the formation and accumulation methane gas and groundwater contamination. Quite apart from the above mentioned damages, dumping of solid waste could also give rise to bad odours, vermin and flies, while litters may spread from the landfill if not properly kept and policed. In addition, the covering and compacting of the solid waste with soil creates airborne dust could prove hazardous to neighbouring residents and passer-by as well.

The economic impact that a landfill has on the value of properties in close proximity to it is important for a number of reasons. First, disparity in prices between like properties different only in distance from a landfill, provide information regarding the welfare effect on households situated in the vicinity. Second, affected property 
owners want to know what effect, if any, the presence of a landfill has or will have on the value of their assets. Third, in the event where a landfill project is subjected to cost-benefit analysis, estimates of property price effects can be incorporated into the cost-benefit profile.

Prior studies on the impact of sanitary landfills on residential properties have found negative relationship between residential house prices and proximity to landfills. Indication via these studies point out that values of residential properties situated within a six kilometre radius from any prominent landfill site rise by approximately 5 to $7 \%$ per $1.6 \mathrm{~km}$ distance away from the said site. Negative value effects have been rarely found for properties located in excess of six kilometres away from landfills. Property values, however, fall more dramatically (i.e. between 21 and 30 percent) the closer (i.e. in a $400 \mathrm{~m}$ to $800 \mathrm{~m}$ radius) the properties are situated to a landfill site. A few recent studies, however, have found no statistically significant relationship existing between house prices and proximity to modern landfills.

This present attempt employs a quantitative approach in ascertaining the price effects of sanitary landfills on proximal residential property values. Section 2 discusses the study area and the subsequent section presents previous study on sanitary landfills and residential property values. Section 4 describes the data collection research methods employed in the study with the data being analysed and discussions in section 5 . Section 6 dealt with the research findings with recommendations presented in section 7. Lastly, section 8 concludes the study.

\section{The Study Area}

Lagos State covers an area of about 3,577 square kilometers, representing $0.4 \%$ of Nigeria's territorial landmass according to Esubiyi (1994). The State shares boundary in the North with Ogun State, West with the Republic of Benin, and stretches for over 180 kilometers North of the Guinea Coast of the Atlantic Ocean. Politically, Lagos State according to Ogunba (1997) had expanded as a result of rural-urban drift and had become a metropolis enclosing settlements such as Mushin, Oshodi, Ikeja, Agege, Shomolu and Bariga.

Lagos State has 16 Local Government Councils as shown in Fig 1 and 57 Local Government Development Areas. Since the metropolis spans across many councils, municipal services are actually carried out by central bodies e.g. the Lagos State Water Corporation (LSWC), the Lagos State Transport Management Agency (LASTMA) and the Lagos State Waste Management Authority (LAWMA).

In 1977, the Lagos State Waste Disposal Board (LSWDB) was formed vide Edict No. 9 of April, 1977 with the mandate to collect and dispose solid waste from commercial and residential sources. In 1980, the refuse Disposal Board was renamed 'Waste Disposal Board' with additional responsibilities of commercial/industrial waste collections and drains cleaning. To ensure compliance by Lagosians of the tenets of environmental laws, Lagos State Environmental Protection Agency (LASEPA), Lagos State Waste Management Authority (LAWMA) and Kick against Indiscipline (KAI) were established.

The regulatory agencies comprised the Ministry of Environment and Planning and the Health Management Board (HMB). Amongst the agencies, LAWMA was particularly vested with the responsibility of monitoring municipal landfills and waste management. Lagos represents all the ideals of property development whether commercial, industrial, recreational or residential. There are four major landfills in Lagos namely Olusosun in Ojota (Ikeja Local Government Area), Abule-Egba, and Solous (Alimosho Local Government) and Gbagada (Kosofe Local Government) respectively under the control and management of Lagos State Waste Management Authority. For the purpose of this study, all four were selected based on their present functional status.

\section{Previous Studies on Sanitary Landfills}

Gamble et al. (1982) estimated hedonic pricing regressions for house sales near a landfill in Boyertown in Pennsylvania. The purpose was to determine the extent of impact the landfill had on surrounding property values. When the distance was split and separate regressions estimated by year of sales, the estimated coefficients for distance to the landfill were not statistically significant at the $5 \%$ level of confidence. One of the estimated implicit prices was even negative implying higher prices closer to the landfill. This result was later cited by Cartee (1989) and Parker (2003) as evidence that modern landfills need not have negative impacts on property values. Though it could be argued that the modern landfill in this context must have incorporated certain inherent qualities that helped lessen the environmental effects of the landfill. Also, the span of the distance split in the above study was not specified so as to show the magnitude of the impact. This present research would address the gap by adopting $1.2 \mathrm{~km}$ radius of the concentric ring to measure the impact of the landfill on value. A linear regression model would be employed at $95 \%$ degree of confidence. 
Havlicek, Richardson and Davies (1985) analysed 182 single family house sales between 1962 and 1970 surrounding four landfills in the Fort Wayne, Indiana region. Their variables of interest were both the linear distance of residential properties from the nearest landfill and the deviation (in absolute degrees) from the prevailing downwind direction from the landfill. Both the distance and the wind variables were of the hypothesised sign and were significant at $5 \%$ confidence level. Their results indicated that for each degree away from downwind, the value of the house increased by about $\$ 10.30$ and for every thirty centimeter of distance away from the site, price increased by about $\$ 0.61$ in a linear fashion. Residents signified their preparedness to pay for more when asked how much more they would be willing to pay for an identical house located a kilometer increment further away from the hazardious waste site. The above study is significant to the current study because the distance variable was a common factor central on both studies. A small sample size of 182 single family house sales was adopted for analysis whereas a larger sample size of 2341 has been adopted in the currrent study. Also, the choice of residential properties as a focus of research introduced a degree of similarity. However, while Havlicek, Richardson and Davies (1985) adopted a linear distance of 1 mile or 1.6 kilometers in their study in a developed country, the present study has adopted 1.2kilometers in view of the fact that in Lagos, the overall pattern of development does not exhibit a well laid out plan like developed countries. One major outstanding feature of their study was the rigour of not only splitting the distance into centimeters, but also ascribing values to residential properties near the landfill. The distance gradient relationship adopted in the current study was 300meters to a maximum of 1200 meters both in linear form and concentric rings.

Cartee (1989) specifically embarked on a study to consider whether sanitary landfills had any adverse effect on community development and residental property values, and if so, measure their magnitudes in selected areas of Pennsylvania. Ten sanitary landfills operating under permits from the Department of Environmental Resources in Pennsylvania were selected for the study. The sanitary landfills were selected based on the presence of residential development in the surrounding communities. The objective was to measure the effects of the landfills on community developments and residential property values. "Study areas" were defined as delineated as those around one mile of the landfills. four randomly selected areas, each one-half mile in diameter, located three miles away from each landfill site constituted the "control areas". Several types of data were collected for the landfill and control areas. These data included the number of properties by size, class, dates of new residential building and proximity of properties to the landfill wth respect to three distance zones. For properties purchased from 1977 to 1981, several other house, lot and locational characteristics were also studied.

The study used multiple regression technique to measure the effect of landfills on residential property values. Regression results showed that in 1977 and 1979, the landfill had no discernable effects on residential property values. In 1978, the "distance to the landfill" variable was significant at $5-10 \%$ level of confidence. This suggests that distance variable was strongly intercorrelated with some other variables. The outcome of the research showed that different sets of property characteristics and different functional forms led to the general conclusion that things other than proximity to the sanitary landfill were more relevant to explaining property values. It can be deduced from the study that the real estate markets are dynamic and local in many respects. Also, landfills are rather heterogeneous varying in size, visibility, accessibility and appearance and that these intervening variables could affect study conclusions.

Reichert, Small and Mohanty (1991) examined the effects of proximity to five municipal landfills in Cleveland, Ohio in the United States. The semi-rural towns studied were Belchertown, Hudson, Ware, Clinton, Pepperrell and Leicester, all located in Central and Western Massachusetts, which had, landfills with varying sizes, operational staus and history of contamination. Using Ordinary Least Squares, inflation adjusted housing prices were regressed upon the series of variables derived from previous studies. Regression results indicated that only one landfill (Pepperell) had a significant negative impact on property values. Although this particular landfill was closed, it was unlined and uncapped, and the fact that the landfill was on the US EPA's "potential health risk" list might have contributed to its visibility in the community. Extrapolated results showed that a typical house located half a mile from the landfill experienced a $6 \%$ rise in property value, while the same increased in value by one percent when located two miles away. This six percent diferential for a house valued at $\$ 120,000$ (the average value for the study) was $\$ 7,200$. However, in respect of Hudson, Ware, Clinton, Pepperell and Leicester, no statistically significant effects were found. The reason coud be that these effects did exist but were not detected in the study or possibly of the small sample sizes drawn on each of the landfills. Overall, the study did not provide grounds for broad generalisation about the effects of rural landfills on property values. It cannot be said that large landfills affect property values more than small ones as Hudson was the largest landfill studied and its effect was statistically insignificant. Open landfills do not affect values more than closed, as Hudson and Ware were still operationing and show no significant effect. Landfills which seem to pose a threat to human 
health may affect property values more than others: Pepperell was on EPA's list as potentialy posing a threat to human health. If the depreciation of local property values around the landfill was a concern of town officals, it seems that the best course of action would be to keep the landfill as clean and policied as possible.

In a more relevant study, Nelson, Genereux and Genereux (1992) studied the effect of a Ramsey, Minnesota landfill on 708 house sales between 1979 and 1989. Their dependent variable was residential property sales' prices, while distance from the landfill, age of house, number of bedrooms and bathrooms were also included as independent variables. The author found that the two landfills had a negative effect on single family house values for homes within 2 mile radius. The study showed that a home located at the boundary of the landfill could suffer a reduction in value of more than $12 \%$ while the value of a property located at one mile radius from the landfill could decrease by an estimated property gradient of $6.2 \%$. The result of this study contrasts with Gamble et al. (1982) who found no negative impact resulting from proximity of residential houses to landfill. Nelson, et al. (1992) adopted 2 miles as the maximum distance.

Bouvier, Halstead, Conway and Malano (2000) estimated hedonic regression for houses located near six landfills in Central and Western Massachussetts, two of which were open and active during the study period. The six landfills differed in size, operating status and history of accumulation. The effect of each landfill was estimated by the use of multiple regressions. In five of the landfills, no statistically significant evidence of an effect was found. In the remaining case, evidence of an effect was found, indicating that houses in close proximity to this landfill suffered an average loss of about $6 \%$ in value. Also, for two of the landfills, the estimated Marginal Implicit Price (MIP) of distance was positive for one distance and negative for the other, but statistically insignificant for both cases. It was observed from the study that the estimated negative coeficient had high sampling variability due to small sample size. The small sample size had thereby introduced some degree of unreliability in the result obtained. The study however established an empirical relationship between residential property values and and proximity to a landfill or set of landfills.

Cambridge Econometrics et al. (2003) conducted economic study of house prices around landfill sites in the United Kingdom that was undertaken as part of a landfill tax review for the Department of Environment, Food and Rural Authority (DEFRA). The study provided additional evidence of an association between proximity to landfill and wealth. The study looked at over half a million sales of houses situated near 11300 U.K landfill sites and found that those properties sited within half a mile of a landfill site suffered statistically significant disadvantages. The value of houses situated less than a quarter of a mile away from the landfill site were an average of $£ 5500$ lower than the value of a similar house not situated near a landfill site. For those houses over a quarter of a mile from the site but under half a mile, the fall in the property value was an average of $£ 1600$ and less than a quater of a mile saw a fall of $40 \%$. Even within the U.K, there were significant regional disparities with the most marked effects in Scotland, where areas in closest proximity to the landfill site (disadvantaged socio-economic groups) may migrate to areas near hazards to take advantage of lower housing prices. This development as shown in the study by Reichert et al (1991) is characteristic of landfill neighbourhoods because as vacancy ratio increases due to the flight of most residents, people of low class take advantage of this to pay lower rent. The distance-value gradient used in the above study would be employed in the current study using concentric rings with the maximum of 1200 meters.

Similarly, Adewusi and Onifade (2006) focused on the effect of urban solid waste on physical environment and property transactions in Surulere Local Government Area of Lagos State. Questionnaires were randomly administered on residents and firms of estate agents to gather data on the subject matter. Data obtained were analysed using frequency tables and percentage ratings. The study found that rents paid on properties adjoining waste dumpsites were lower compared to similar properties further away and also, property transaction rates were very slow and unattractive as one approaches a dumpsite. However, the study did not monetary explicit on the change in values.

In the same vein, Bello (2007) used multiple regression analysis to determine the effect of waste dumpsites on property values in Olusosun neighbourhood at Ojota, Lagos State. The study found that property values increase with distance away from dumpsites. Also, Bello and Bello (2008) conducted a research on the willingness to pay for environmental amenities in Akure Nigeria. The study included environmental amenities such as waste water disposal, water and electricity supplies, neighbourhood roads and other locational services. The study used a two-staged hedonic model to examine the willingness to pay for better environmental services by residents of two neighbourhoods in Akure, Nigeria. He combined multiple regressions and predictive model to determine property values as a function of housing attributes and logistic model as willingness to pay. The study identified households' income, distance away from the refuse dump site and regularity of electricity supply as the major factors that influenced household's willingness to pay for better environmental services. The study 
recommended economic empowerment of the people, diligent consideration in the location of dumpsites and adoption of Public-Private Initiative in the provision of public infrastructure. The study established that real estate values are readily influenced by residents williongness to pay for both structural as well as neighbourhood characteristics where the real estate is located. However, Bello and Bello (2008) failed to relate property values with distance from the waste dump site as an environmental disamenity. This present study fills this gap.

Bello (2009) carried out a study on the effects of waste dump sites on proximate property values in Lagos, Nigeria using three dump sites located at Olusosun, Abule Egba and Solous adopting $1 \mathrm{~km}$ distance measurement to assess the effects of the dumpsite on the neighbourhoods. The research sampled 334 residents from the three waste dump sites and 107 Estate Surveying and Valuation firms in metropolitan Lagos. The study was in the main to measure the effect of waste dump on property values and to develop an appropriate valuation methodology to carry out valuation of properties affected by waste dump sites. A combination of valuation methodologies was adopted such as Paired Sales Analysis, Contingent Valuation Analysis, Option Pricing Model and Hedonic Approach. The study found that there was a weak linear relationship between rental value and satisfaction of occupants in the neighbourhood of the waste dumps.

In a very recent research, Akinjare et al. (2011), the impact of four operational sanitary landfills (Gbagada, Olusosun, Abule-Egba and Solous) on proximal residential properties in Lagos metropolis of Nigeria was studied using a sample size of 2341 residents. Inclusively, 229 Estate Surveyors and 315 Lagos State Waste Management Agency (LAWMA) officials provided data for the study. Evaluation using a hedonically derived regression function in analysing data estimates drawn from administered questionaires showed a slight evidence of statistical significance indicating that all residential property values increased with distances away from landfill sites at an average of $6 \%$ for the four landfills.

This study attempts to determine the relationship between distance from these landfills and residential property values. Obtainable results will form a good basis for understanding property market behaviour and consequently draw a comparison between the above study and this current one for the purpose of empirical generalisations. Of paramount note, however, is the simple fact that the attributes of the present study are similar to most of the principal attributes of the above study. The present study used relative distance from municipal landfills as a variable to measure their impacts on residential property values in metropolitan Lagos which in all ramifications shared similarities with Cleveland in Ohio, USA especially in the display of urban characteristics. This research adopted a linear regression for individual analysis for individual landfills instead of multiple regression used for the six landfills in Cleveland, Ohio. The essence is to appreciate differences in the pattern of value impact of the landfills in relation to residential properties.

\section{Data Collection and Research Methods}

Primary data were collected through questionnaires distributed to Estate Surveyors and Valuers, residents residing within $1.2 \mathrm{~km}$ to the four landfills as well as officials of the Lagos State Waste Management Agency (LAWMA). The survey involved every third houses within $1.2 \mathrm{~km}$ distances from the 4 landfill sites(Figure 2). The responses are as follows; Gbagada -(848), Olusosun -(674), Abule-Egba -(422) and Solous -(397). Inclusively, 229 Estate Surveyors and 315 Lagos State Waste Management Agency officials returned questionnaires administered to them. The survey recorded an average response rate of $78 \%$ and collated data were analysed using a descriptive and analytical statistics.

Since the impacts of a landfill on nearby residential property values are not expected to be uniform as ascertained by literature, values are expected to increase with distance away from the landfill, the concentric ring model was then used in analysing landfill impacts on residential property values.

The relationship between landfill and property values was measured in a distance of $1.2 \mathrm{~km}$ radius away from the landfill location. Measurement was based on interval of 300meters up to 1200 meters in concentric rings. Thus, the impact from the landfill could be calculated at a specific distance away in Nairage value.

\section{Data Analysis and Discussion}

Information gathered were analysed as shown in Tables $1-4$. From Table 1, it is observed that while the various type residential properties around the Gbagada landfill location increases as the distance away from the landfill increases, property values of various residential properties increase outwardly. The analysis of Table 1 revealed that $9.4 \%$ of the houses were located within $0-300$ meters, $22.4 \%$ were within $301-600$ meters, $31.6 \%$ located within $601-900 \mathrm{~m}$ and another $36.6 \%$ located within $901-1200$ meters.

Table 2 analyses the impact of Olusosun landfill on adjacent and neighbouring properties with the 1200 meter radial perimeter and a consistent pattern of residential property distribution is observed. The number of 
residential properties increase as distance away from the landfill increases. Consistently, property values towed the same line as those obtainable at Gbagada. The Table indicates that $9.4 \%$ of residential properties were located within 0-300 meters radial diameter, $22.4 \%$ were within $301-600$ meters, $31.6 \%$ located within $601-900$ meters while the remaining $36.6 \%$ were within the $901-1200$ meter range.

Again, the analysis of Table 3 vividly indicates residential property values within the 1200 meter radial confines of the Abule Egba in relation to distance. This table again confirms the appreciation in residential property value with increased distance from the landfill. Within the radial range, $8.8 \%$ of residential properties were located within 0-300 meters, $23.2 \%$ were within 301-600 meters, $26.5 \%$ located within $601-900$ meters while $41.5 \%$ were within the 901-1200 meter zone.

As represented in Table 4, values for residential properties of all cadres around Solous landfill followed the same trend of increased value with increased distance. Observations indicated that $6.3 \%$ of the houses were located within $0-300$ meters, $21.7 \%$ were within $301-600$ meters, $30 \%$ located within $601-900 \mathrm{~m}$ and another $42 \%$ located within 901-1200 meters. Lastly, Table 5 shows details of the average total monetary value of residential property investment within $1200 \mathrm{~m}$ of all four landfills totalling 649,000 and also the appreciation of properties as distance away from these landfills increase. The least appreciation of $4 \%$ was observed to occur for properties within the neighbourhood of Gbagada while an appreciation of $6 \%$ was noted for Olusosun and Abule Egba environs respectively. Appreciation within the neighbourhood of Solous was highest at 7\%.

\section{Research Findings}

Across the four neighbourhoods, the survey revealed that an increase in property value was evident as distance away from the landfill increased. There was an indication that the highest property values were recorded for properties betweeen the $601 \mathrm{~m}$ and $900 \mathrm{~m}$ range from the landfill. There was no threat posed by the landfill to properties beyond the $900 \mathrm{~m}$ concentric ring. Also, the study showed that $30.2 \%$ of residential properties were situated within the $601 \mathrm{~m}$ and $900 \mathrm{~m}$ distance range from the landfills while $41.4 \%$ of residential properties were situated between $901 \mathrm{~m}$ and $1200 \mathrm{~m}$ boundary.

Furthermore, the study showed that in order to mitigate the adverse impacts of the landfill on residential property values, amenities such as health centers, bore holes, street lighting facilities in a bid to enhance these plagued neighbourhoods.

\section{Recommendations}

The study recommends that instead of Government turning burrowed pits into landfills, the site selection criteria as enuciated by Luthbom and Lagerkvist (2003) with respect to distance between landfills and settlements, occurence of surface water, ground water, ecological and hydro geological conditions on and around the site, existing and pending laws and regulations and transport systems and communications should be considered exhaustively. Despite governments efforts at environmental sustainability presently, it is recommended that landfill within fully developed residential city centers should be closed down and relocated. Solous, Abule Egba and Olusosun were not pleasant to sight and thus an urgent need for action plans and education by LAWMA in order to improve the monitoring, control and projection of solid waste expected in the nearest future. There is the need to expand recycling programmes through modern methods with a view of turning waste to wealth in metropolitan Lagos.

Finally the support of the private sector and NGOs is also required most especially in the area of organising maintenance workshops and enlightenment programs which should include the grassroots participation and input.

\section{Conclusions}

This current study has established that there is a negative correlation between landfills and proximal residential property values within the 300 meter demarcated concentric rings extending to $1.2 \mathrm{~km}$. It is therefore, hoped that if the Lagos State Government is able to look into the recommended solutions the quality of the environment will be enhanced and this will positively affect residential property values in cities on a general scale.

\section{References}

Adewusi, A. O., \& Onifade. F. A. (2006). The effects of urban solid waste on physical environment and property transactions in Surulere local government area of Lagos state. Journal of Landuse and Development Studies, 2 (1), 71-90.

Akinjare, O. A., Ayedun, C. A., Oluwatobi, A. O., \& Iroham, O. C. (2011). Impact of sanitary landfills on urban residential property value in Lagos State, Nigeria. Journal of Sustainable Development, 4(2),48-60. 
Bello, V. A. (2007). The effects of Ojota waste dump site on surrounding property values in Lagos metropolis. Journal of Environmental Conservation and Research, 1(1\&2), 136-142.

Bello, M. O., \& Bello, V. A. (2008). Willingness to pay for better environmental services: Evidence from the Nigerian real estate market. Journal of African Real Estate Research, 1(1), 19-27.

Bello, V. A. (2009). The effects of waste dump sites on proximate property values in lagos Nigeria, (Unpublished Ph.D Dessert), Federal University of Technology, Akure, Nigeria.

Bouvier, Halstead, Conway, \& Malano, (2000). The effect of landfill on rural residential property values: Some empirical analysis. Journal of Regional Analysis and Policy, 370(2), 23-33.

Cambridge Econometrics, EFTEC and WRC. (2003). The disamenity costs of landfills. Department of Environment and Rural Affairs, HMSO.

Cartee, C. (1989). A review of sanitary landfill impacts on property values. Real Estate Appraiser and Analyst, (Spring), 43-47.

Esubiyi, A. O. (1994). Obsolescence and property values: A case study of Lagos. Unpublished BSc Dissertation Submitted to the Department of Estate Management, Obafemi Awolowo University, Ile-Ife.

Gamble, H. B., Downing, R. H., Shortle, J. S., and Epp, D. J. (1982). Effects of solid waste disposal sites on community development and residential property values. Final Report for The Bureau of Solid Waste Management (Department of Environmental Resources, Commonwealth of Pennsylvania).

Havlicek, J. (1985). Impact of solid waste disposal on property values. Environmental Policy Solid Waste, Volume IV, Cambridge, MA: Ballinger.

Luthbom, K., \& Lagerkvist, A. (2003). Tools for landfill siting. Ninth International Waste Management and Landfill Symposium, S. Margherita di Pula (Cagliari), Sardinia, Italy

Nelson, A. C., John, G., \& Michelle, G. (1992). Price effects of landfills on house values. Land Economics, 68(4), 359-365.

Ogunba, O. A. (1997). A study of valuation and pricing methods in the residential property market in Lagos Metropolis. An Unpublished M.Sc. Dissertation Submitted to the Department of Estate Management, Obafemi Awolowo University, Ile Ife.

Parker, B. J. (2003). Solid waste landfills and residential property values. White Paper, National Solid Wastes Management Association, Washington, DC.

Reichert, A. K., Small, M., \& Mohanty, S. (1991). The impact of landfills on residential property values. The Journal of Real Estate Research, 7(3), 297-314.

Table 1. Cross-Tabulation of Mean Property Values and Distances of Properties Around Gbagada Landfill (=N=Millions)

\begin{tabular}{|c|c|c|c|c|c|c|c|c|c|c|c|c|}
\hline \multirow{3}{*}{$\begin{array}{c}\text { Distance in } \\
\text { Meters }\end{array}$} & \multicolumn{12}{|c|}{ Residential Property Type } \\
\hline & \multicolumn{2}{|c|}{$\begin{array}{c}\text { Tenement } \\
\text { House }\end{array}$} & \multicolumn{2}{|c|}{$\begin{array}{c}\text { 4nos, } 3 \mathrm{~b} / \mathrm{r} \\
\text { Flats }\end{array}$} & \multicolumn{2}{|c|}{$\begin{array}{c}\text { 4b/r } \\
\text { Duplex }\end{array}$} & \multicolumn{2}{|c|}{$\begin{array}{c}4 \mathrm{~b} / \mathrm{r} \\
\text { Detached }\end{array}$} & \multicolumn{2}{|c|}{$\begin{array}{c}5 \mathrm{~b} / \mathrm{r} \\
\text { Detached }\end{array}$} & \multirow[t]{2}{*}{$\begin{array}{c}\text { No of } \\
\text { Property }\end{array}$} & \multirow[t]{2}{*}{$\begin{array}{l}\% \text { of } \\
\text { Total. }\end{array}$} \\
\hline & Freq. & P.V & Freq. & P.V & Freq. & P.V & Freq. & P.V & Freq. & P.V & & \\
\hline $0-300$ & 30 & 3.4 & 33 & 5 & 14 & 7 & 3 & 9 & 0 & - & 80 & 9.4 \\
\hline $301-600$ & 57 & 5.4 & 73 & 7 & 19 & 9 & 27 & 11 & 14 & 13.5 & 190 & 22.4 \\
\hline $601-900$ & 64 & 6.5 & 89 & 9 & 31 & 11 & 41 & 11 & 43 & 15 & 268 & 31.6 \\
\hline $901-1200$ & 52 & 7.5 & 101 & 10 & 53 & 11 & 48 & 12 & 56 & 15 & 310 & 36.6 \\
\hline Total & & & & & & & & & & & 848 & 100.0 \\
\hline
\end{tabular}

Source: Statistical Analysis, 2010 
Table 2. Cross-Tabulation of Mean Property Values and Distances of Properties Around Olusosun Landfill $(=\mathrm{N}=$ Millions $)$

\begin{tabular}{|c|c|c|c|c|c|c|c|c|c|c|c|c|}
\hline \multirow{3}{*}{$\begin{array}{l}\text { Distance } \\
\text { in Meters }\end{array}$} & \multicolumn{12}{|c|}{ Residential Property Type } \\
\hline & \multicolumn{2}{|c|}{$\begin{array}{c}\text { Tenement } \\
\text { House }\end{array}$} & \multicolumn{2}{|c|}{$\begin{array}{c}\text { 4nos, } 3 \mathrm{~b} / \mathrm{r} \\
\text { Flats }\end{array}$} & \multicolumn{2}{|c|}{$\begin{array}{c}4 \mathrm{~b} / \mathrm{r} \\
\text { Duplex }\end{array}$} & \multicolumn{2}{|c|}{$\begin{array}{c}4 \mathrm{~b} / \mathrm{r} \\
\text { Detached }\end{array}$} & \multicolumn{2}{|c|}{$\begin{array}{c}5 \mathrm{~b} / \mathrm{r} \\
\text { Detached }\end{array}$} & \multirow[t]{2}{*}{$\begin{array}{c}\text { No of } \\
\text { Property }\end{array}$} & \multirow[t]{2}{*}{$\begin{array}{l}\% \text { of } \\
\text { Total }\end{array}$} \\
\hline & Freq. & P.V & Freq. & P.V & Freq. & P.V & Freq. & P.V & Freq. & P.V & & \\
\hline $0-300$ & 0 & - & 8 & 4.5 & 8 & 6 & 5 & 6 & 9 & 7.5 & 30 & 4.5 \\
\hline $301-600$ & 12 & 2.5 & 34 & 6.5 & 31 & 8 & 25 & 8 & 16 & 9.5 & 118 & 17.5 \\
\hline $601-900$ & 30 & 4 & 58 & 8 & 69 & 10 & 31 & 11 & 32 & 10.5 & 220 & 32.6 \\
\hline $901-1200$ & 62 & 4 & 72 & 9 & 63 & 11 & 59 & 11 & 50 & 11 & 306 & 45.4 \\
\hline Total & & & & & & & & & & & 674 & 100.0 \\
\hline
\end{tabular}

Source: Statistical Analysis, 2010

Table 3. Cross-Tabulation of Mean Property Values and Distances of Properties Around Abule-Egba Landfill $(=\mathrm{N}=$ Millions $)$

\begin{tabular}{|c|c|c|c|c|c|c|c|c|c|c|c|c|}
\hline \multirow{3}{*}{$\begin{array}{c}\text { Distance in } \\
\text { Meters }\end{array}$} & \multicolumn{12}{|c|}{ Residential Property Type } \\
\hline & \multicolumn{2}{|c|}{$\begin{array}{c}\text { Tenement } \\
\text { House }\end{array}$} & \multicolumn{2}{|c|}{$\begin{array}{c}\text { 4nos, } 3 \mathrm{~b} / \mathrm{r} \\
\text { Flats }\end{array}$} & \multicolumn{2}{|c|}{$\begin{array}{c}4 \mathrm{~b} / \mathrm{r} \\
\text { Duplex }\end{array}$} & \multicolumn{2}{|c|}{$\begin{array}{c}4 \mathrm{~b} / \mathrm{r} \\
\text { Detached }\end{array}$} & \multicolumn{2}{|c|}{$\begin{array}{c}5 \mathrm{~b} / \mathrm{r} \\
\text { Detached }\end{array}$} & \multirow[t]{2}{*}{$\begin{array}{c}\text { No of } \\
\text { Property }\end{array}$} & \multirow[t]{2}{*}{$\begin{array}{l}\% \text { of } \\
\text { Total. }\end{array}$} \\
\hline & Freq. & P.V & Freq. & P.V & Freq. & P.V & Freq. & P.V & Freq. & P.V & & \\
\hline $0-300$ & 6 & 1.5 & 10 & 3 & 5 & 4.5 & 2 & 6 & 2 & 7.5 & 25 & 6.3 \\
\hline $301-600$ & 19 & 2.5 & 19 & 5.5 & 11 & 6.5 & 27 & 7 & 10 & 9 & 86 & 21.7 \\
\hline 601-900 & 23 & 3.5 & 24 & 6.5 & 18 & 8 & 39 & 9 & 15 & 10 & 119 & 30.0 \\
\hline $901-1,200$ & 29 & 4.5 & 38 & 7.5 & 27 & 8 & 56 & 10 & 19 & 11 & 167 & 42.0 \\
\hline Total & & & & & & & & & & & 397 & 100.0 \\
\hline
\end{tabular}

Source: Statistical Analysis, 2010

Table 4. Cross-Tabulation of Mean Property Values and Distances of Properties Around Solous Landfill $(=\mathrm{N}=$ Millions $)$

\begin{tabular}{|c|c|c|c|c|c|c|c|c|c|c|c|c|}
\hline \multirow{3}{*}{$\begin{array}{l}\text { Distance in } \\
\text { Meters }\end{array}$} & \multicolumn{12}{|c|}{ Residential Property Type } \\
\hline & \multicolumn{2}{|c|}{$\begin{array}{c}\text { Tenement } \\
\text { House }\end{array}$} & \multicolumn{2}{|c|}{$\begin{array}{c}4 \text { nos, } 3 \mathrm{~b} / \mathrm{r} \\
\text { Flats }\end{array}$} & \multicolumn{2}{|c|}{$\begin{array}{c}4 \mathrm{~b} / \mathrm{r} \\
\text { Duplex }\end{array}$} & \multicolumn{2}{|c|}{$\begin{array}{c}4 \mathrm{~b} / \mathrm{r} \\
\text { Detached }\end{array}$} & \multicolumn{2}{|c|}{$\begin{array}{c}5 \mathrm{~b} / \mathrm{r} \\
\text { Detached }\end{array}$} & \multirow[t]{2}{*}{$\begin{array}{c}\text { No of } \\
\text { Property }\end{array}$} & \multirow[t]{2}{*}{$\begin{array}{r}\% \text { of } \\
\text { Total }\end{array}$} \\
\hline & Freq. & P.V & Freq. & P.V & Freq. & P.V & Freq. & P.V & Freq. & P.V & & \\
\hline $0-300$ & 14 & 1.5 & 6 & 4.5 & 9 & 5 & 3 & 6 & 5 & 8.5 & 37 & 8.8 \\
\hline $301-600$ & 22 & 2.5 & 26 & 7.5 & 24 & 6 & 10 & 8 & 16 & 10.5 & 98 & 23.2 \\
\hline 601-900 & 31 & 4 & 24 & 8 & 21 & 10 & 17 & 11 & 19 & 12.5 & 112 & 26.5 \\
\hline $901-1200$ & 64 & 4 & 41 & 8 & 27 & 10 & 22 & 11 & 21 & 13.5 & 175 & 41.5 \\
\hline Total & & & & & & & & & & & 422 & 100.0 \\
\hline
\end{tabular}

Source: Statistical Analysis, 2010

Table 5. Estimated Average Residential Property Value Across the 4 Landfill Sites

\begin{tabular}{|l|l|l|}
\hline Landfill Sites & $\begin{array}{c}\text { Estimated Neighbourhood Property Value } \\
=\mathrm{N}=(000,000)\end{array}$ & \multicolumn{1}{c|}{$\begin{array}{c}\text { \% Property Value Appreciation Away From } \\
\text { Landfill }\end{array}$} \\
\hline Gbagada & 1,674 & 4 \\
\hline Olososun (Ojota) & 5,772 & 6 \\
\hline Abule Egba & 2,873 & 6 \\
\hline Solous (Igando) & 3,126 & 7 \\
\hline Average & 3,361 & 5.75 \\
\hline
\end{tabular}

Source: Statistical Analysis, 2010 


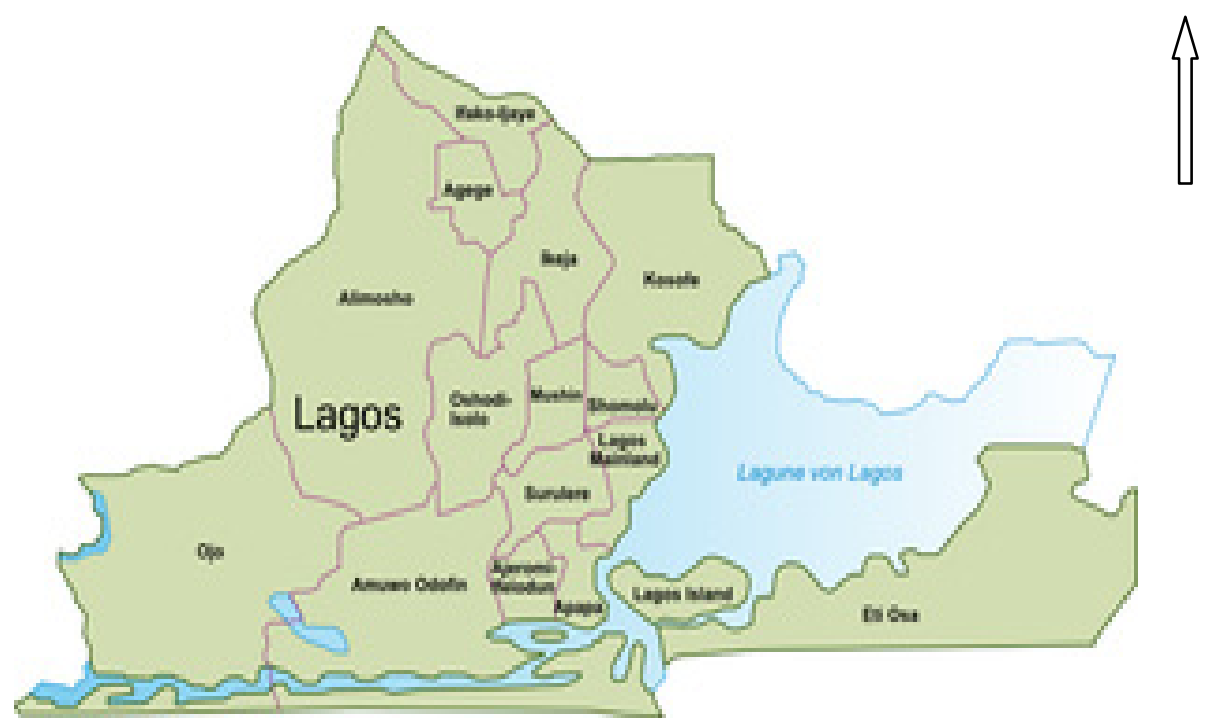

Figure 1. Map of Metropolitan Lagos

Source: Lagos State Ministry of Information

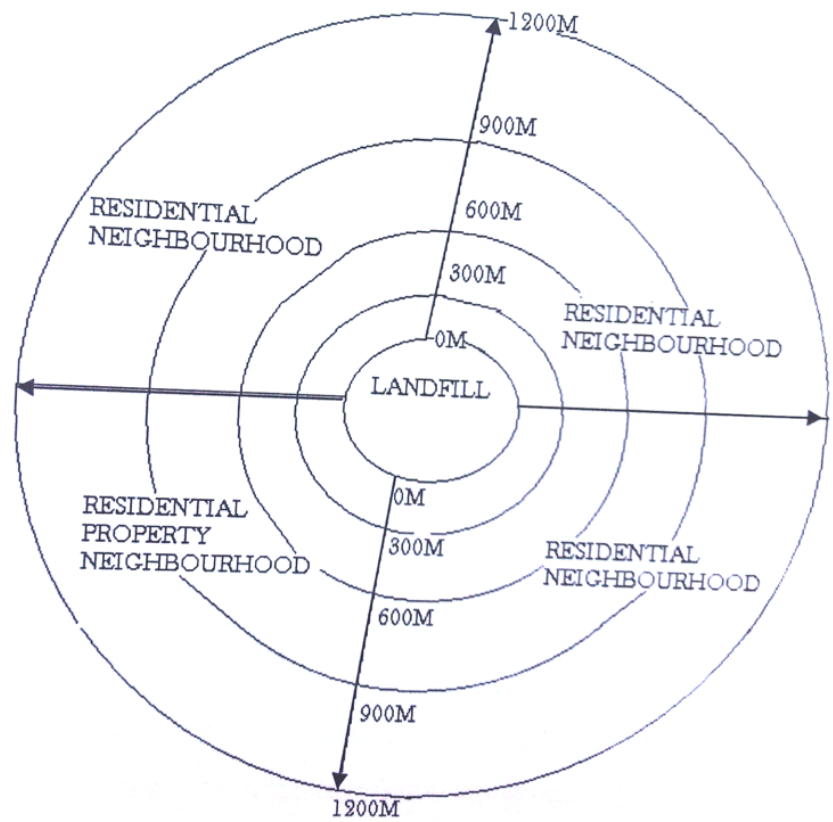

Figure 2. Distance-Value Gradient in Concentric Rings

Source: Author's Construct, (2010) 